\title{
Predation by a dinoflagellate on a red microalga with a cell wall modified by sulfate and nitrate starvation
}

\author{
Michal Ucko ${ }^{1,2}$, Shimona Geresh ${ }^{1}$, Bracha Simon-Berkovitch ${ }^{1}$, \\ Shoshana Arad (Malis) ${ }^{1, *}$
}

${ }^{1}$ The Institutes for Applied Research, Ben-Gurion University of the Negev, PO Box 1025, Beer-Sheva 84110, Israel

${ }^{2}$ Israel Oceanographic and Limnologic Research Ltd, PO Box 1212, Elat 88112, Israel

\begin{abstract}
The dinoflagellate Crypthecodinium cohnii was found to prey specifically on the unicellular red alga Porphyridium sp. and to contain enzymes that degrade its cell wall. Cell wall production and composition of the alga are affected by nitrate and sulfate deprivation, the main changes being an increase in methylhexose and a decrease in glucose and xylose. When the dinoflagellate was fed with Porphyridium sp. having modified cell walls, fewer cells were ingested. Similarly, in chemosensory experiments it was found that the dinoflagellate was more attracted to the native polysaccharide than to polysaccharides extracted from deprived Porphyridium sp. Polysaccharide-degrading activity was higher when the dinoflagellate was fed with nondeprived algal cells than with deprived cells (82 to $86 \%$ and 45 to $53 \%$ reduction in viscosity, respectively). Although the dinoflagellate could not survive on polysaccharide alone, the induced enzymatic activity was similar irrespective of whether the polysaccharide was extracted from deprived or nondeprived cells. The results indicate that the process of predation is not linked to polysaccharide-degrading activity, which is affected by the cell-wall composition of the prey, i.e. algal cells
\end{abstract}

KEY WORDS: Crypthecodinium - Dinoflagellate - Porphyridium - Rhodophyta $\cdot$ Sulfated polysaccharide $\cdot$ Cell wall $\cdot$ Starvation

\section{INTRODUCTION}

Heterotrophic microflagellates feed on a wide range of prey (Kimor 1979, Goldman et al. 1989). Some are selective, the selectivity being a function of size, structure, shape, or composition of the prey's cells and the morphology of the cytosome ('cell mouth') of the predator (Capriulo 1982, Lessard \& Swift 1985, Andersson et al. 1986, Barlow et al. 1988). The phagocytic cell recognizes its prey before ingestion occurs. Recognition is manifested by cell-to-cell adhesion, which probably depends on the surface properties of the 2 cells. Ryter \& De Chastellier (1983) proposed that during cellular recognition at least 3 properties of the cell

- Addressee for correspondence surface must be considered: specific receptors, electrostatic charges, and hydrophobic properties. In many cases of phagocytic interaction, phagocytosis-specific molecules are indeed essential for adhesion and recognition (Wright \& Silverstein 1986)

A heterotrophic dinoflagellate isolated by us from an outdoor cultivar of the red microalga Porphyridium $\mathrm{sp}$. was originally thought to be Gymnodinium sp. (Ucko et al. 1989). It has, however, recently been identified as Crypthecodinium cohnii, a heterotrophic dinoflagellate that has been studied in some detail (Gold \& Baren 1966, Hauser et al. 1975, Tuttle \& Loeblich 1975, Beam \& Himes 1982, 1987). This dinoflagellate was found to grow only on the cells of the red microalga Porphyridium sp., but not on other microalgae or on a medium alone (Ucko et al. 1989). We also found that the dinoflagellate contains enzymes that 
degrade the polysaccharide cell wall of Porphyridium $\mathrm{sp}$. but not that of other red microalgae. The enzymatic activity of the dinoflagellate and the degradation products have previously been characterized (Simon et al. 1992, 1993).

The cells of the red microalgae are encapsulated within a sulfated polysaccharide (Ramus 1973). The polysaccharide is a sulfated heteropolymer made up of about 10 different sugars and a protein moiety (Geresh \& Arad 1991).

It has previously been shown that nitrate and sulfate starvation affect the cell ultrastructure of the red microalgae (Köst et al. 1984, Wanner \& Köst 1984). Nitrate starvation inhibits cell division and enhances cell wall polysaccharide production (Köst et al. 1984, Thepenier et al. 1985, Arad 1988, Arad et al. 1988). A similar response was found under sulfate starvation (Arad 1988, Arad et al. 1992). Cell recognition and adhesion events are known to be mediated by sulfated polysaccharides (Coombe et al. 1987).

The present study is based on the hypothesis that the dinoflagellate specifically recognizes the polysaccharide cell wall of its prey, the alga. Since nitrate and sulfate deprivation induce changes in the cell wall composition of Porphyridium sp. cells, we used these algae with altered cell walls to examine predation and growth in the dinoflagellate. The attraction between the dinoflagellate and algal polysaccharide was also studied.

\section{MATERIALS AND METHODS}

Organisms and growth conditions. Porphyridium sp. (UTEX 637) was grown in artificial seawater (ASW) according to Jones et al. (1963) in 1 l columns $(6 \mathrm{~cm}$ in diameter) at $24 \pm 1{ }^{\circ} \mathrm{C}$. The cultures were illuminated continuously with fluorescent light lamps at an irradiance of $150 \mu \mathrm{E} \mathrm{m}^{-2} \mathrm{~s}^{-1}$. The cultures were aerated with sterile air containing 3 to $4 \% \mathrm{CO}_{2}$.

In the nitrogen starvation experiments, Porphyridium sp. cells were inoculated into nitrate-free ASW. Sulfate starvation was achieved by growing the algal cells 3 cycles prior to the experiment in ASW supplemented with $\mathrm{MgCl}_{2} \cdot 6 \mathrm{H}_{2} \mathrm{O}\left(10.24 \mathrm{~g} \mathrm{l}^{-1}\right)$ and $\mathrm{Na}_{2} \mathrm{SO}_{4}$ $\left(0.0623 \mathrm{~g} \mathrm{l}^{-1}\right)$ instead of $\mathrm{MgSO}_{4}$.

The dinoflagellate (formerly reported to be Gymnodinium sp.) was isolated from outdoor ponds of Porphyridium sp. with a micropipette. Recently, the dinoflagellate was identified as Crypthecodinium cohnii by M. Elbrächter \& E. Schnepf (pers. comm). Cultures of the dinoflagellate were maintained at $20 \pm$ $1^{\circ} \mathrm{C}$ in $3 \mathrm{l}$ Erlenmeyer flasks containing $1.5 \mathrm{l}$ of ASW supplemented with cells of Porphyridium sp. cultivated on ASW from the stationary phase of growth. For certain experiments the dinoflagellates were fed with Porphyridium sp. starved of nitrogen or sulfate (as described in the previous paragraph). The cultures were aerated with sterile air, and illumination was supplied from the side at an intensity of $50 \mu \mathrm{E} \mathrm{m}^{-2} \mathrm{~s}^{-1}$. During the experiments the cultures were grown in $40 \mathrm{ml}$ test tubes containing $5 \mathrm{ml}$ of medium. Growth was followed by periodic monitoring of cell numbers with a light microscope by means of a hemocytometer. The movement of dinoflagellate cells was arrested with $4 \%$ formaldehyde. Predation was measured by counting the number of algal cells in a $C$. cohnii cell with the aid of an epifluorescence microscope.

The effect of different treatments on the ingestion of Porphyridium sp. was analyzed by ANOVA and Duncan's multiple range test-SAS (Sokal \& Rohlf 1969). Variance was tested for normality and homogeneity (Hartley's F-max test; Sokal \& Rohlf 1969). (The critical level of significance for testing the hypothesis was $p<0.005$.)

Chemosensory experiments. In order to maximize the motility and the chemosensory response of $C$. cohnii the dinoflagellate cells were starved by growing them in ASW 48 to $72 \mathrm{~h}$ before the experiment. In the chemosensory response assays, micropipettes $(10 \mu \mathrm{l} \pm$ $0.25 \%$ Brand Cat. No. 708709) were filled with the following polysaccharides $(0.1 \%)$ and then sealed with a tube sealer: Porphyridium sp. (native, starved of nitrate, or starved of sulfate); Rhodella reticulata; and carrageenan (Type J, The Copenhagen Pectin Factory Ltd, Denmark). The control was ASW. The chemosensory response assays were conducted as follows: starved dinoflagellates $\left(1.5\right.$ to $2 \times 10^{4}$ cells $\left.\mathrm{ml}^{-1}\right)$ were added to a plastic petri dish in which 15 or 16 micropipettes filled with the various polysaccharides had been placed. After $2 \mathrm{~h}$ at $20 \pm 1^{\circ} \mathrm{C}$ the number of dinoflagellates in the capillary tubes was determined by means of a hemocytometer. The chemosensory ratio was the number of dinoflagellates entering the polysaccharide-containing pipettes divided by the number of dinoflagellates entering the control (Verity 1988).

Dinoflagellate enzymatic extract. Dinoflagellate cultures (total of $2 \times 10^{8}$ cells), 14 h old, were centrifuged for $10 \mathrm{~min}$ at $11000 \times \mathrm{g}$. The pellet was suspended in $15 \mathrm{ml}$ Tris-maleate buffer $(0.1 \mathrm{M}, \mathrm{pH} 6.7)$, and the cells were broken by freezing in liquid nitrogen and thawing thereafter ( 5 times). The crude extract was centrifuged for $30 \mathrm{~min}$ at $18000 \times g$, and the supernatant was used as the enzyme preparation.

Preparation of algal cell wall polysaccharides. Cultures of Porphyridium sp. grown in ASW or in ASW without nitrate or sulfate were centrifuged $(20 \mathrm{~min}$ at $27500 \times g)$ to separate the cells from the growth medium containing the soluble fraction of the cell wall polysaccharide. The supernatant was dialyzed against doubly distilled water (until the conductivity of the 
water reached 25 to $30 \mathrm{~m} \Omega$ ). The supernatant was then frozen and lyophilized.

Enzyme assay. Dinoflagellate enzymatic extract $(2 \mathrm{ml})$ was added to $0.2 \%$ of polysaccharides (substrate) dissolved in $6 \mathrm{ml}$ of Tris-maleate buffer $(0.1 \mathrm{M}$, $\mathrm{pH} 6.7$ ), supplemented with $0.1 \%$ sodium azide. The mixture was incubated at $30^{\circ} \mathrm{C}$ in a shaker bath for $24 \mathrm{~h}$. Enzyme(s) activity was determined by measuring the decrease in viscosity of the solution by means of a Brookfield Digital Viscometer (spindle 18, sample volume $8 \mathrm{ml}$, speed $30 \mathrm{rpm}$ ).

GC analysis of sugar composition. The polysaccharides were hydrolyzed in $2 \mathrm{~N}$ trifluoroacetic acid for $2 \mathrm{~h}$ at $100^{\circ} \mathrm{C}$, and derivatized to the corresponding alditol acetates. The monosaccharides were identified with a Varian GC equipped with a methylsilicon column (Supelco sp. 2100, $30 \mathrm{~m}, \mathrm{~d}=0.25 \mu \mathrm{m}$ ) and a flame ionization detector (myoinositol was used as the internal standard; Albersheim et al. 1967).

\section{RESULTS}

The composition of polysaccharides extracted from Porphyridium sp. starved of nitrate and sulfate is shown in Table 1. The main differences were found in the amounts of 2,4-O-MeO-hexose, xylose, and glucose. Methylhexose increased from $1.3 \%$ in the native polysaccharide to $>20 \%$; xylose was reduced from 40.9 to $\leq 18 \%$; and glucose was reduced from 14.5 to $\leq 8 \%$ in both nitrate and sulfate starvation. The best growth of the dinoflagellate was observed when it was

Table 1 Sugar composition of the Porphyridium sp. polysaccharide deprived of nitrate or sulfate. Data represent the \% of each sugar of total sugars in each polysaccharide. Bold values indicate sugars with major differences in composition. Results are the average of 2 different batches of polysaccharide. Sugars were identified by GC according to the alditol acetate method (Albersheim et al. 1967). Carbohydrate content of the native polysaccharide was $67 \%$ and that of the nitrate- and sulfatedeprived polysaccharide was $77 \%$ and $67 \%$, respectively

\begin{tabular}{|lccc|}
\hline \multirow{2}{*}{$\begin{array}{c}\text { Sugar } \\
\text { polysaccharide }\end{array}$} & \multicolumn{2}{c|}{$\begin{array}{l}\text { Polysaccharide from } \\
\text { cultures deprived of: } \\
\text { Nitrate }\end{array}$} & Sulfate \\
\hline 3-O-MeO-pentose & 0.06 & 0.50 & 0.50 \\
Rhamnose & 0.49 & 3.20 & 3.04 \\
Arabinose & 0.52 & 1.7 & 1.30 \\
Xylose & $\mathbf{4 0 . 9}$ & $\mathbf{9 . 8}$ & $\mathbf{1 8 . 0 7}$ \\
Mannose & 10.01 & 0.40 & 6.19 \\
Glucose & $\mathbf{1 4 . 5}$ & $\mathbf{4 . 2 0}$ & $\mathbf{8 . 1 4}$ \\
Galactose & 23.8 & $\mathbf{4 0 . 7 5}$ & 29.7 \\
2,4-O-MeO-hexose & $\mathbf{1 . 3}$ & $\mathbf{2 7 . 1 8}$ & $\mathbf{2 0 . 8 8}$ \\
Glucuronic acid & $\mathbf{7 . 0 2}$ & 11.3 & 11.6 \\
Methyl galactose & 1.4 & - & - \\
\hline
\end{tabular}

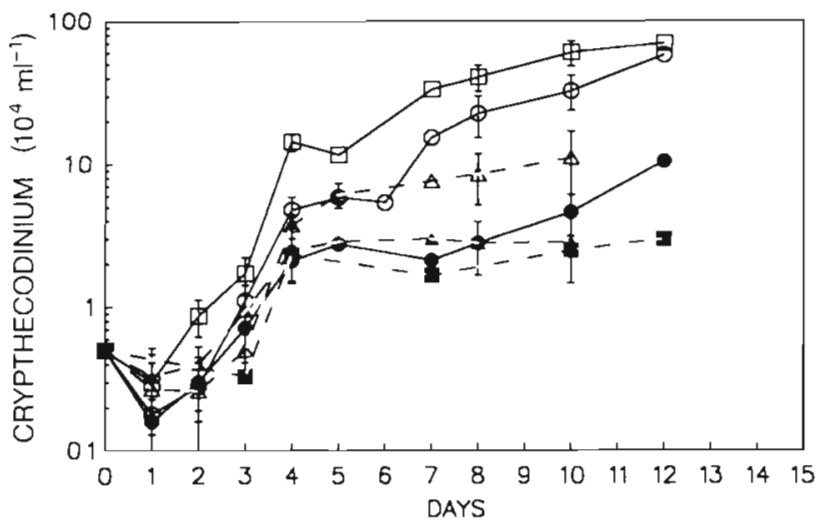

Fig. 1. Effect of nitrate or sulfate deprivation of Porphyridium $\mathrm{sp}$. on the growth of dinoflagellate cells. Dinoflagellate cells $\left(0.5 \times 10^{4} \mathrm{cells} \mathrm{m}^{-1}\right)$ were inoculated into Porphyridium sp. cultures $\left(3 \times 10^{6}\right.$ cells $\left.\mathrm{ml}^{-1}\right)$ that were: $(\square)$ grown on ASW before and during the experiment, $(\boldsymbol{\Delta})$ starved of nitrate before and during the experiment, $(\Delta)$ starved of nitrate before but not during the experiment, ( ) deprived of sulfate before and during the experiment, (O) starved of sulfate before but not during the experiment. (四) Dinoflagellate cells inoculated into a growth medium without algae. Bars $=S E$

fed with nondeprived Porphyridium sp. cells. The poorest growth was found for dinoflagellates fed with algal cells deprived of nitrate or sulfate before and during the experiment (Fig. 1). The ingestion by the dinoflagellate of nondeprived Porphyridium sp. (Table 2) was significantly different $(p<0.005)$ from that of deprived (of sulfate or nitrate) cells. This finding was particularly marked in the group containing 10 to 17 algal cells per dinoflagellate cell.

The chemotactic response of the dinoflagellates to the native polysaccharide ( 55 to $30 \%$ ) was greater than that to nitrate- or sulfate-deprived polysaccharides (Table 3). Polysaccharides from another species of red microalga Rhodella reticulata and from a red seaweed were also found to be less attractive than the native polysaccharide.

The enzymatic activities of the dinoflagellates in degrading the polysaccharide are shown in Table 4. The highest activities ( 82 to $86 \%$ decrease in viscosity) were observed in enzymes from dinoflagellate cells fed with algae cultivated in ASW, the source of the substrate - the polysaccharide - having almost no effect. However, when the dinoflagellates were fed with starved (of nitrate or sulfate) Porphyridium sp., their enzymatic activity was significantly lower (only 45 to $53 \%$ decrease in viscosity).

Addition of polysaccharide extracted from Porphyridium sp. to the dinoflagellate induced its enzymatic activities (results not shown). The source of the polysaccharide (native or deprived of nitrate or sulfate) did not affect the activity (92 to $97 \%$ decrease in viscosity after 14 h of growth). 
1984, Wanner \& Köst 1984, Thepenier et al. 1985, Arad 1988, Arad et al. 1988). In this study we show for the first time that the sugar composition of the deprived polysaccharide was also modified. It is interesting to note that the pattern of change in cell wall composition was similar for nitrate and sulfate deprivation, the main changes being an increase in methylhexose accompanied by a decrease in glucose and xylose. We thus assume that the hexose in the methylhexose is glucose. This has to be further confirmed. It is likely that the protein in the cell wall was also modified, which in turn might affect the overall properties of the cell wall. Moreover, this change might be the main factor affecting the attraction to the algal cell.

The differences in the chemosensory responses of the dinoflagellate cells to the various polysaccharides support our hypothesis that the recognition between the predator and its prey is based on the cell wall composition of the prey. These results are also in accordance with the growth and predation experiments. Crypthecodinium cohnii has previously been shown to be attracted to a variety of chemical compounds, such as sugars and amino acids (Hauser et al. 1975, Spero 1985), and a more detailed study of the chemosensory attractants of our isolate of $C$. cohnii is under way.

The dinoflagellate enzymatic activity was measured in a crude extract preparation by measuring the changes in viscosity. The fact that we have used a crude preparation and the means we used to measure enzyme activity did not allow us to determine specific activity. We did, however, use identical numbers of cells in each enzymatic preparation so that the effect of starvation on growth of the dinoflagellates was not involved in this measurement.

We have previously shown (Ucko et al. 1989) that the dinoflagellate cannot grow solely on the polysaccharide extracted from Porphyridium sp. but requires whole algal cells. However, under these conditions polysaccharide-degrading activity is induced (Simon et al. 1992), even when the polysaccharides are modified by starvation. Thus, it seems to us that predation is not necessarily related to digestion, for which polysaccharide-degrading activity is essential.

The reason why the dinoflageliate ingests Porphyridium sp., i.e. whether the dinoflagellate requires the cell-wall polysaccharide or the intracellular matter, is becoming clearer Based on the results obtained here, it seems to us that the induction of polysaccharide-degrading enzymes enables the dinoflagellate to peel off the algal cell wall so that it can digest the intracellular matter. As a result, within the dinoflagellate cells there appeared protoplasts of Porphyridium $\mathrm{sp}$. that had been ingested by the dinoflagellate cells. This preliminary observation has to be studied further.
Acknowledgements. The authors thank Prof. Elbrächter (Taxonomische Arbeitsgruppe an der Biologischen Anstalt Helgoland, Wattenmeerstation List/Sylt, Germanyl and Prof. Schnepf (Zellenlehre, University of Heidelberg, Germany) for their helpful advice on identification of the dinoflagellate and Ms I. Mureinik for styling the manuscript.

\section{LITERATURE CITED}

Albersheim, P. D., Nevins, J., English, P. D., Karr, A. (1967). A. method for the analysis of sugars in plant cell wall polysaccharide by gas-liquid chromatography. Carbohydr Res. 5: 340-345

Andersson, A., Larsson, U., Hagstrom, A. (1986). Size selective grazing by a microflagellate on pelagic bacteria. Mar. Ecol Prog. Ser. 33: 51-57

Arad (Malis), S. (1988). Production of sulfated polysaccharides from unicellular red algae. In: Stadler, T., Mollion, J., Verdus, M.-C., Karamanos, Y., Morvan, H., Christiaen, D. (eds.) Algal biotechnology. Elsevier Applied Science, London, p. 65-87

Arad (Malis), S., Friedman, O. (Dahan), Rotem, A. (1988). Effect of nitrogen on polysaccharide production in a Porphyridium sp. Appl. environ. Microbiol. 54: 2411-2414

Arad (Malis), S., Lerental-Brown, Y., Dubinsky, O. (1992). Effect of nitrate and sulfate starvation on polysaccharide formulation in Rhodella reticulata. Bioresource Technol. 42: $141-148$

Barlow, R. G., Burkill, P. H., Mantoura, R. F. C. (1988). Grazing and degradation of algal pigments by marine protozoan Oxyrthis marina. J. exp. mar. Biol. Ecol. 119: 119-129

Beam, C. A., Himes, M. (1982). Distribution of members of the Crypthecodinium cohnii (Dinophyceae) species complex. J. Protozool. 29(1): 8-15

Beam, C. A., Himes, M. (1987). Electrophoretic characterization of members of the Crypthecodinium cohnii (Dinophyceae) species complex. J. Protozool. 34(2): 204-217

Butler, N. M., Suttle, C. A., Neill, W. E. (1989). Discrimination by fresh water zooplankton between single algal cells differing in nutritional status. Oecologia 78: 368-372

Capriulo, G. M. (1982). Feeding of field collected tintinnid microzooplankton on natural food. Mar. Biol. 71: 73-86

Coombe, D. R., Jakobsen, K. B., Parish, C. R. (1987). A role for sulfated polysaccharide recognition in sponge cell aggregation. Expl Cell Res. 170; 381-401

Cowles, T. J., Olson, R. J., Chisholm, S. W. (1988). Food selection by copepods: discrimination on the basis of food quality. Mar. Biol. 100: 41-49

Geresh, S., Arad (Malis), S. (1991). The extracellular polysaccharides of the red microalgae: chemistry and rheology, Bioresource Technol. 38: 195-201

Gold, K., Baren, C. F. (1966). Growth requirements of Gyrodinium cohrui. J. Protozool. 13: 255-257

Goldman, J. C., Dennett, M. R., Gordin, H. (1989). Dynamics of herbivorous grazing by the heterotrophic dinoflagellate Oxyrihis marina. J. Plankton Res. 11: 391-407

Hauser, D. C. R., Levandowsky, M., Hunter, S. H., Chunosoff, L., Hollwitz, J. S. (1975). Chemosensory responses by the heterotrophic marine dinoflagellate Crypthecodinium cohnii. Microb. Ecol. 1: 246-254

Jones, R. F., Speer, H. L., Kury, W. (1963). Studies on the growth of the red alga Porphyridium cruentum. Physiol. plant. 16: 636-643

Kimor, B. (1979). Predation by Noctiluca miliaris Souriray on Acartia tonsa Dana eggs in the inshore water of southern California. Limnol. Oceanogr. 24: 568-572 
Köst, H. P., Senser, M., Wanner, G. (1984). Effect of nitrate and sulfate starvation on Porphyridium cruentum cells. Z. Pflanzenphysiol. 1135: 231-249

Lessard, E. J., Swift, E. (1985). Species-specific grazing rates of heterotrophic dinoflagellate in oceanic waters measured with a dual-label radioisotope technique. Mar. Biol. 87: $289-296$

Ramus, J. (1973). Cell surface polysaccharides of the red algae Porphyridium. In: Loewus, F. (ed.) Biogenesis of plant cell wall polysaccharides. Academic Press, New York, p. 333-359

Ryter, A., De Chastellier, C. (1983). Phagocytic-pathogenic microbe interactions. Int. Rev. Cytol. 85: 287-319

Simon, B., Geresh, S., Arad (Malis), S. (1992). Degradation of the cell wall polysaccharide of Porphyridium sp. (Rhodophyta) by means of enzymatic activity of its predator, Gymnodinium sp. (Pyrrophyta). J. Phycol. 28 $460-465$

Simon, B., Geresh, S., Arad (Malis), S. (1993). Polysaccharidedegrading activities extracted during growth of a dinoflagellate that preys on Porphyridium sp. Plant Physiol. Biochem. 31(3): 387-393

Sokal, R. R., Rohlf, F. J. (1969). Biometry. The principles and

This article was submitted to the editor practice of statistics in biological research. W. H. Freeman \& Co., San Francisco

Spero, H. J. (1985). Chemosensory capabilities in the phagotrophic dinoflagellate Gymnodinium fungiforme J. Phycol. 21. 181-184

Thepenier, C., Gudin, C., Thomas, D. (1985). Immobilization of Porphyridium cruentum in polyurethane foam for the production of polymers. Biomass 7: 225-240

Tuttle, R. C., Loeblich, A. R. III (1975). An optimal growth medium for the dinoflagellate Crypthecodinium cohnii. Phycologia 14(1): 1-8

Ucko, M., Cohen, E., Gordin, H., Arad (Malis), S. (1989). Relationship between the unicellular red alga Porphyridium sp. and its predator, the dinoflagellate Gymnodinium sp. Appl. environ. Microbiol. 55: 2990-2994

Verity, P. G. (1988). Chemosensory behavior in marine planktonic ciliates. Bull. mar. Sci. 43(3): 772-782

Wanner, G., Köst, H. P. (1984). 'Membrane storage' of the red alga Porphyridium cruentum during nitrate and sulfate starvation. Z. Pflanzenphysiol. 1135: 251-262

Wright, S. D., Silverstein, S. C. (1986). Handbook of experimental immunology, Vol. 2, Cellular immunology. Blackwell Scientific Publications, Oxford, p. 41

Manuscript first received: January 27, 1993

Revised version accepted: November 11, 1993 